\title{
Productivity Growth in the Transportation Industries in the United States: An Application of the DEA Malmquist Productivity Index
}

\author{
Jaesung Choi ${ }^{*}$, David C. Roberts ${ }^{2}$, EunSu Lee ${ }^{3}$ \\ ${ }^{1}$ Transportation and Logistics Program, North Dakota State University, Fargo, ND, USA \\ ${ }^{2}$ Department of Agribusiness \& Applied Economics, North Dakota State University, Fargo, ND, USA \\ ${ }^{3}$ Upper Great Plains Transportation Institute, North Dakota State University, Fargo, ND, USA \\ Email: ;jaesung.choi@ndsu.edu, David.C.Roberts@ndsu.edu, eunsu.lee@ndsu.edu
}

Received 21 October 2014; revised 20 November 2014; accepted 12 December 2014

Copyright (C) 2015 by authors and Scientific Research Publishing Inc.

This work is licensed under the Creative Commons Attribution International License (CC BY). http://creativecommons.org/licenses/by/4.0/

c) (i) Open Access

\begin{abstract}
This study reviews productivity growth in the five major transportation industries in the United States (airline, truck, rail, pipeline, and water) and the pooled transportation industry from 2004 to 2011. We measure the average productivity for these eight years by state in each transportation industry and the annual average productivity by transportation industry. The major findings are that the U.S. transportation industry shows strong and positive productivity growth except that in the years of the global financial crisis in 2007, 2008, and 2010, and among the five transportation industries, the rail and water sectors show the highest productivity growth in 2011.
\end{abstract}

\section{Keywords}

DEA Malmquist Productivity Index, Productivity Growth, U.S. Transportation Industry

\section{Introduction}

Transportation is an important part of development and growth in economic activities. When a transportation industry is efficient, it can provide more economic and social benefits to residents, businesses, and the government through the decrease of congestion, just-in-time business work, and environmental pollution caused by an inefficient transportation mode. When a transportation industry is deficient, however, it leads to unexpected op-

${ }^{*}$ Corresponding author.

How to cite this paper: Choi, J., Roberts, D.C. and Lee, E.S. (2015) Productivity Growth in the Transportation Industries in the United States: An Application of the DEA Malmquist Productivity Index. American Journal of Operations Research, 5, 1-20. http://dx.doi.org/10.4236/ajor.2015.51001 
portunity costs or lost business opportunities. In many developed countries, the proportion of transportation to Gross Domestic Product (GDP) ranges from 6\% to 12\% [1]. The transportation industry in the United States has long had a major effect on growth at the city, region, and state levels.

The U.S. transportation industry is one of the largest in the world. The U.S. Department of Transportation explains in its freight shipments report that the transportation industry brings together more than seven million domestic businesses and 288 million citizens with the employment of one out of seven U.S. workers. It is noted that “more than $\$ 1$ out of every $\$ 10$ produced in the U.S. GDP is related to transportation activity" [2].

The increase in productivity in an industry occurs when growth in output is proportionately greater than growth in inputs. In the transportation industry, the measure of productivity growth has been an important issue for both transportation economists and transportation policymakers for centuries. A number of attempts have been made to solve this issue, with Data Envelopment Analysis (DEA) popular for the analysis of productivity gains. DEA has three main advantages: 1) The number of empirical applications is very large; 2) It does not place any restrictions on the assumption of the inefficiency term and technology; 3) A production relationship regarding the form of the frontier between inputs and outputs is not restricted [3]-[8].

The productivity growth of efficiency and technological change in various industries including transportation has been studied. For example, Farrell [9] measured productive efficiency based on price and technical efficiencies in U.S. agricultural production for the 48 states in 1952. The two key concepts used to measure a farmer's success were choosing the best set of inputs and producing the maximum output from a given set of inputs, respectively. Unlike Farrell [9], Charnes et al. [10] provided a nonlinear programming model to define efficiency and thus evaluated the performance of nonprofit public entities. In 1982, Caves et al. [11] developed an index number procedure for input, output, and productivity, while Sueyoshi [12] provided an effectively designed algorithmic procedure for the measurement of technical, allocative, and overall efficiencies. These were provided as a basis to construct a Malmquist productivity index, which was later developed by Färe et al. [3], Färe and Grosskopf [4], and Färe et al. [5] [6]. In 1992, Färe et al. [3] [5] developed the Malmquist input-based productivity index to measure productivity growth in Swedish pharmacies and in 1994 used the Malmquist outputbased productivity index to analyze productivity growth in industrialized countries and Swedish hospitals.

Following Färe and Grosskopf [4], a unified theoretical explanation of three productivity indexes (Malmquist, Fisher, and Törnqvist) was provided. In the 2000s, research started to compare the conventional Malmquist productivity index with an environmentally sensitive Malmquist productivity index in applications of the U.S. agricultural industry, the U.S. trucking industry, and 10 OECD countries [13]-[15].

Nevertheless, the conventional Malmquist productivity index has still been used to measure productivity growth. For example, Chen and Ali [16] employed it for the productivity measurement of seven computer manufacturers in the Fortune Global 500 from 1991 to 1997, while Liu and Wang [17] applied it to Taiwan's semiconductor industry during 2000 to 2003. Recently, the high-tech industry in China and Turkish electricity distribution industry have been analyzed to measure efficiency performance by Qazi and Yulin [18] and Celen [8], respectively.

The growth of the U.S. transportation industry has been led by the five major transportation modes: truck, rail, airline, pipeline, and water. For the past ten years, their growth patterns have been more complicated in the age of limitless competition based on the needs of the times, obtainable output profits from the input resources available, and levels of technological advances in each industry. The objective of this study utilizes the conventional Malmquist productivity index to measure productivity growth in these five major transportation industries in 51 U.S. states as well as the pooled transportation industry between 2004 and 2011. The state-level findings from this study are expected to be used to evaluate whether each state's transport policies have sufficiently functioned to enhance productivity growth at its boundary. The structure of the remainder of this paper is as follows. Section 2 explains the methodology used and Section 3 describes the data. In Section 4, the results of the empirical analysis are shown and Section 5 concludes the study.

\section{Methodology}

Let us define:

$$
\begin{aligned}
& x^{t}=\text { Input vector from time period, } t=1, \cdots, T . \\
& y^{t}=\text { Output vector from time period, } t=1, \cdots, T . \\
& S^{t}=\text { Production technology that } x^{t} \text { can produce } y^{t} .
\end{aligned}
$$


Four output distance functions are required to calculate the output-based Malmquist productivity index, and the first distance function is defined as follows [3]-[6]:

$$
D_{0}^{t}\left(x^{t}, y^{t}\right)=\inf \left\{\theta:\left(x^{t}, y^{t} / \theta\right) \in S^{t}\right\}
$$

The first distance function means the maximum change in outputs using a set of given inputs with the technology at $t$, and it should be less than or equal to 1 if and only if $\left(x^{t}, y^{t}\right) \in S^{t}$. If $D_{0}^{t}\left(x^{t}, y^{t}\right)=1$, then it means that $\left(x^{t}, y^{t}\right)$ is on the technology frontier.

The mixed-period hyperbolic distance function in Equation (2) evaluates the maximum change in outputs using a set of $t+1$ inputs compared with the $t$ benchmark technology:

$$
D_{0}^{t}\left(x^{t+1}, y^{t+1}\right)=\inf \left\{\theta:\left(x^{t+1}, y^{t+1} / \theta\right) \in S^{t}\right\}
$$

In Equation (3), the mixed-period distance function for the maximum change in outputs using a set of $t$ inputs with the benchmark technology at $t+1$ is evaluated:

$$
D_{0}^{t+1}\left(x^{t}, y^{t}\right)=\inf \left\{\theta:\left(x^{t}, y^{t} / \theta\right) \in S^{t+1}\right\}
$$

The fourth distance function evaluates the maximum change in outputs using a set of $t+1$ inputs compared with the $t+1$ benchmark technology:

$$
D_{0}^{t+1}\left(x^{t+1}, y^{t+1}\right)=\inf \left\{\theta:\left(x^{t+1}, y^{t+1} / \theta\right) \in S^{t+1}\right\}
$$

Following Färe et al. [3] and Färe et al. [5] [6], the output-based Malmquist productivity index is defined as

$$
M_{0}^{t+1}\left(x^{t+1}, y^{t+1}, x^{t}, y^{t}\right)=\left[\frac{D_{0}^{t}\left(x^{t+1}, y^{t+1}\right)}{D_{0}^{t}\left(x^{t}, y^{t}\right)} \frac{D_{0}^{t+1}\left(x^{t+1}, y^{t+1}\right)}{D_{0}^{t+1}\left(x^{t}, y^{t}\right)}\right]^{1 / 2}
$$

The equivalent index is redefined as

$$
M_{0}^{t+1}\left(x^{t+1}, y^{t+1}, x^{t}, y^{t}\right)=\frac{D_{0}^{t+1}\left(x^{t+1}, y^{t+1}\right)}{D_{0}^{t}\left(x^{t}, y^{t}\right)}\left[\frac{D_{0}^{t}\left(x^{t+1}, y^{t+1}\right)}{D_{0}^{t+1}\left(x^{t+1}, y^{t+1}\right)} \frac{D_{0}^{t}\left(x^{t}, y^{t}\right)}{D_{0}^{t+1}\left(x^{t}, y^{t}\right)}\right]^{1 / 2}
$$

The output-oriented method measures how much output quantities can proportionally increase without increasing input quantities [19]. Equation (5) is the geometric mean of two Malmquist productivity indexes, and in Equation (6), the output-based Malmquist productivity index is converted into two terms: the first term out of the square brackets indicates the efficiency change between two periods, $t$ and $t+1$, while the geometric mean of the second term in the square brackets captures technical progress in period $t+1$ and $t$. If the value of the output-based Malmquist productivity index in Equation (6) is equal to one, then no productivity growth occurs between these two periods, whereas if it is more (less) than one, there is positive (negative) productivity growth between these two periods. Efficiency and technological change have the same interpretation. For example, zero means nothing happens; however, if greater (less) than one, there is positive (negative) change [3]-[6].

\section{Data}

The data in this study consist of three proxies for inputs and one proxy for output in the five major transportation industries in the U.S. between 2004 and 2011 ${ }^{1}$. The output-based Malmquist productivity index requires only data for inputs and output(s): input data are yearly intermediate inputs such as energy, materials, and purchasedservice inputs and output data is represented by annual GDP, which is equivalent to value added. The Bureau of Economic Analysis (BEA) defines the composition of gross output by industry as the summation of intermediate inputs and value added [20]. The BEA, however, only provides to the public yearly intermediate inputs data at the national level for each industry, not by state. Therefore, the extent of taxes that each state collected in the

\footnotetext{
${ }^{1}$ This study has some limitations due to the data. Heterogeneity caused by exogenous economic shocks-i.e. shocks caused by general recessions, rather than by the transportation sector. To reduce the introduction of statistical bias and/or inconsistency, data prior to the economic recovery of 2004 were eliminated. The final year of the study uses data from 2011, however, so the possibility of bias and/or inconsistency still exists.
} 
transportation industries from 2004 to 2011 were used to estimate the best-possible approximation for intermediate inputs by state over time. This is based on the assumption that more taxes paid by a transportation industry in a state means more purchased inputs to produce output. For example, if the state of North Dakota collected \$4 billon in its air transportation industry in 2004 compared with $\$ 10,229$ billion in the U.S. airline transportation industry, then each energy, materials, and purchased-service input for the airline transportation industry in North Dakota is calculated by multiplying the proportion of $\frac{4}{10,229}$ by the national level of each intermediate input. All data were obtained from the online database of the BEA in 2013, and they are measured in millions of dollars [21].

Table 1 shows that the values of output produced have been proportionally increasing with those of the intermediate inputs used in the airline, truck, rail, and water transportation industries from 2004 to 2011 excluding 2009, which shows a slight decrease in output values; the pipeline transportation industry has been decreasing in terms of the input values used. The value of gross output in each transportation industry is occupied in order for the truck, airline, rail, water, and pipeline transport modes. Truck transportation is the largest transportation industry in terms of GDP, almost equal to the sum of the production values of the other four industries. The truck and airline transportation industries show much more intensive usages of energy and service inputs compared with materials inputs; that might be attributed to their fundamental industry structures. The pooled transportation industry summarizes the change in the three intermediate inputs utilized: materials inputs consist of much lower amounts compared with energy and purchased-service inputs.

\section{Empirical Results}

The traditional Malmquist productivity indexes for each transportation industry as well as the pooled transportation industry are estimated in Table 3 to Table 9, by using DEA Programming (DEAP) 2.1. First, in Table 3 to Table 8, the average productivity for the eight years by state for each transportation industry is shown. Second, Table 9 provides the annual average productivities for the transportation industries over time. In these tables, the sources of productivity growth are decomposed into an efficiency change component and a technological change component. Färe et al. [5] defined efficiency change as catching up, that is how much closer a state can approach the ideal frontier in a transportation industry, and technological change as an innovation, namely how much the ideal frontier shifts because of the existing technology.

In Table 2, the three non-parametric statistical tests such as Median test, Kruskal-Wallis test, and Van der Waerden test are tested to evaluate the validity of the Malmquist productivities in each transportation industry and the pooled transportation industry. Their null hypothesis of the six population distribution functions (airline, truck, rail, pipeline, water, and pooled transportation industries) are identical is rejected at the $1 \%$ significance level. This implies that the Malmquist productivities by state in the five major transportation industries and the pooled transportation industry show significantly different [22].

Table 3 shows the Malmquist productivity and its decomposition in the pooled model of the U.S. transportation industry from 2004 to 2011. On average, a positive productivity growth of $0.5 \%$ by state is shown, which is attributed to a $4.6 \%$ efficiency growth and a technological decline of $3.9 \%$. This finding means that the transportation industry in a state has marginally increased growth on average, while its innovation movement is far below the efforts of catching up to the frontier. All states experience negative growth in technological change on average; therefore, if productivity growth in a state is positive, this suggests that its technological decline is offset or surpassed by an efficiency gain. Altogether, 28 states $^{2}$ show positive productivity growth, and of these, the Malmquist productivity changes in the following 17 states average at least 10\%: New York, North Carolina, North Dakota, Ohio, Oklahoma, Oregon, South Carolina, South Dakota, Tennessee, Texas, Utah, Vermont, Virginia, Washington, West Virginia, Wisconsin, and Wyoming. Figure 1 depicts the geographic representation of average productivity for the eight years by state in the pooled transportation industry: Malmquist productivity < 1, productivity decline; Malmquist productivity $=1$, no change in productivity; Malmquist productivity $>1$, productivity growth.

The productivity measurement in the U.S. transportation industry by state is now described more in detail

\footnotetext{
${ }^{2} 28$ states are as follows: Florida, Kansas, Kentucky, Louisiana, Maine, Maryland, Massachusetts, Michigan, Minnesota, New York, North Carolina, North Dakota, Ohio, Oklahoma, Oregon, Pennsylvania, Rhode Island, South Carolina, South Dakota, Tennessee, Texas, Utah, Vermont, Virginia, Washington, West Virginia, Wisconsin, and Wyoming.
} 
Table 1. Annual GDP (value added) and intermediate inputs in each transportation industry and the pooled transportation industry, 2004-2011 (unit: billions of dollars).

\begin{tabular}{|c|c|c|c|c|c|c|c|c|}
\hline Airline transportation & 2004 & 2005 & 2006 & 2007 & 2008 & 2009 & 2010 & 2011 \\
\hline GDP & 56.1 & 55.7 & 59.7 & 60.2 & 59.9 & 59.4 & 66.1 & 69.6 \\
\hline Intermediate inputs & 66.4 & 74.5 & 80.5 & 89.6 & 101 & 72.1 & 79.8 & 92.1 \\
\hline Energy inputs & 18.1 & 27.1 & 29.6 & 40.1 & 49.6 & 25.6 & 33 & 41.8 \\
\hline Materials inputs & 2.1 & 1.5 & 1.8 & 2.6 & 2.7 & 1.9 & 1.9 & 2.3 \\
\hline Purchased-service inputs & 46.2 & 46 & 49.1 & 46.9 & 48.7 & 44.6 & 44.8 & 48 \\
\hline Truck transportation & 2004 & 2005 & 2006 & 2007 & 2008 & 2009 & 2010 & 2011 \\
\hline GDP & 110.7 & 119.6 & 125.3 & 127.2 & 122.3 & 114.8 & 119.8 & 126 \\
\hline Intermediate inputs & 122 & 136.8 & 148.4 & 153.7 & 162.1 & 116.2 & 128.5 & 149.1 \\
\hline Energy inputs & 30.1 & 41.1 & 46.8 & 50.9 & 60.4 & 35.5 & 35.1 & 50 \\
\hline Materials inputs & 13.3 & 13.8 & 14.7 & 18.5 & 17.6 & 13.8 & 13.6 & 16 \\
\hline Purchased-service inputs & 78.6 & 81.9 & 86.9 & 84.2 & 84.1 & 67 & 79.7 & 83.1 \\
\hline Rail transportation & 2004 & 2005 & 2006 & 2007 & 2008 & 2009 & 2010 & 2011 \\
\hline GDP & 24.3 & 27 & 30.6 & 31.7 & 35.1 & 31 & 32.2 & 36.7 \\
\hline Intermediate inputs & 26.4 & 32 & 36.6 & 38 & 43.4 & 32.4 & 43.7 & 49.1 \\
\hline Energy inputs & 3.5 & 5.7 & 6.8 & 7.7 & 11.2 & 4.9 & 8.4 & 10.8 \\
\hline Materials inputs & 5.5 & 6 & 6.7 & 7.7 & 9.6 & 6.9 & 8.9 & 9.8 \\
\hline Purchased-service inputs & 17.4 & 20.3 & 23.1 & 22.6 & 22.6 & 20.7 & 26.4 & 28.5 \\
\hline Pipeline transportation & 2004 & 2005 & 2006 & 2007 & 2008 & 2009 & 2010 & 2011 \\
\hline GDP & 8.3 & 8.9 & 11.7 & 12.8 & 14.3 & 13.9 & 13.8 & 14.5 \\
\hline Intermediate inputs & 11.9 & 12.8 & 13.6 & 14.1 & 14.1 & 10.3 & 8.3 & 6.4 \\
\hline Energy inputs & 1 & 1.1 & 1.2 & 1.1 & 1.5 & 0.5 & 0.7 & 0.6 \\
\hline Materials inputs & 2.2 & 2.2 & 2.4 & 2.4 & 2.3 & 1.4 & 1.3 & 1 \\
\hline Purchased-service inputs & 8.7 & 9.4 & 10.1 & 10.6 & 10.4 & 8.4 & 6.3 & 4.8 \\
\hline Water transportation & 2004 & 2005 & 2006 & 2007 & 2008 & 2009 & 2010 & 2011 \\
\hline GDP & 31.3 & 34.8 & 36.6 & 39.6 & 41.3 & 42.8 & 43.5 & 45.6 \\
\hline Intermediate inputs & 22.4 & 21.7 & 19.2 & 21.6 & 23.3 & 21.5 & 23.3 & 25.4 \\
\hline Energy inputs & 7.7 & 9.1 & 7.3 & 10.1 & 11.1 & 6.9 & 9.9 & 12.7 \\
\hline Materials inputs & 1.7 & 1.3 & 1.4 & 1.9 & 1.8 & 1.8 & 1.3 & 1.5 \\
\hline Purchased-service inputs & 13 & 11.2 & 10.5 & 9.7 & 10.4 & 12.8 & 12.1 & 11.2 \\
\hline Pooled transportation & 2004 & 2005 & 2006 & 2007 & 2008 & 2009 & 2010 & 2011 \\
\hline GDP & 230.7 & 246 & 263.9 & 271.5 & 272.9 & 261.9 & 275.4 & 292.4 \\
\hline Intermediate inputs & 249.1 & 277.8 & 298.3 & 317 & 343.9 & 252.5 & 283.6 & 322.1 \\
\hline Energy inputs & 60.4 & 84.1 & 91.7 & 109.9 & 133.8 & 73.4 & 87.1 & 115.9 \\
\hline Materials inputs & 24.8 & 24.8 & 27 & 33.1 & 34 & 25.8 & 27 & 30.6 \\
\hline Purchased-service inputs & 163.9 & 168.8 & 179.7 & 174 & 176.2 & 153.5 & 169.3 & 175.6 \\
\hline
\end{tabular}


Table 2. Non-parametric statistical tests to assess the validity of the Malmquist productivities.

\begin{tabular}{cc}
\hline Statistical tests & $P$ values \\
Median test & $<0.0001^{* * * *}$ \\
Kruskal-Wallis test & $<0.0001^{* * *}$ \\
Van der Waerden test & $<0.0001^{* * * *}$ \\
\hline
\end{tabular}

Notes: the null hypothesis of the three tests is that the six population distribution functions are identical; ${ }^{* * *}$ Indicates significance at $1 \%$.

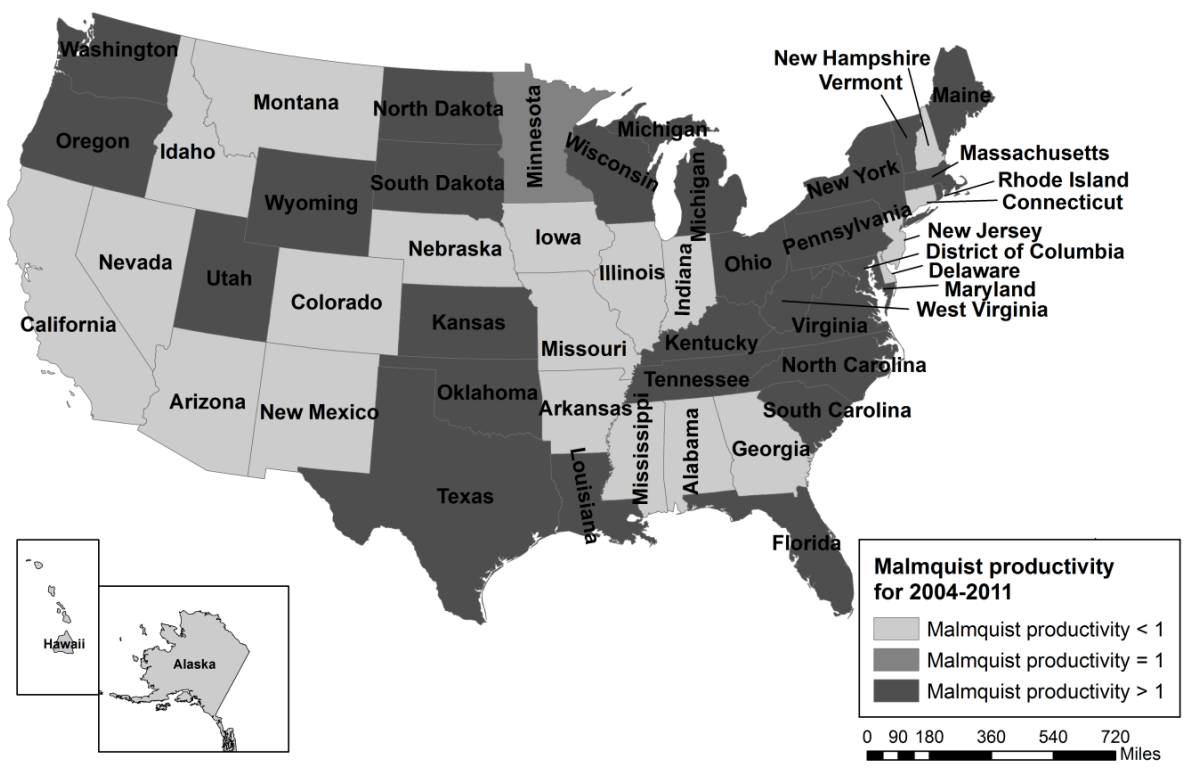

Figure 1. Geographic representation of average Malmquist productivity for 2004-2011 by state in the pooled transportation industry.

with the results of the five major transportation industries. Table 4 shows the changes in Malmquist productivity, efficiency, and technology in the airline transportation industry between 2004 and 2011. Productivity growth by state averages close to zero due to the increase of $1 \%$ in efficiency change and the decrease of $1.1 \%$ in technological change; therefore, the airline transportation industry by state on average shows that growth itself might be stuck at zero or at worst showing a slight decline during the study period. Nevertheless, 27 of the 51 states show positive productivity growth, with Texas and Wyoming having the highest growth of 10.3\%. Figure 2 depicts the geographic representation of average productivity for 2004-2011 by state in the airline transportation industry.

Table 5 shows the Malmquist productivity and its decomposition in the truck transportation industry from 2004 to 2011. On average, a negative productivity growth of $2.2 \%$ per state is shown and this is decomposed into an efficiency gain of $0.6 \%$ and a technological decline of $2.7 \%$. The truck industry in each state shows all negative technological changes, implying that innovation has declined over time on average; however, the productivity growth changes in the 20 states on average show non-zero growth due to the high levels of catching up. It is noted that productivity growth in Kansas, Kentucky, and Louisiana is much higher than that in the other 20 states with positive growth $(19.1 \%, 16.7 \%$, and $16.5 \%$, respectively). Figure 3 depicts the geographic representation of average productivity for 2004-2011 by state in the truck transportation industry.

In Table 6, the changes in Malmquist productivity, efficiency, and technology in the rail transportation industry are shown between 2004 and 2011. On average, the rail transportation industry by state shows a negative productivity growth of $1.1 \%$ based on a decrease of $5.2 \%$ in efficiency change and an increase of $4.3 \%$ in technological change. The results of the rail industry are interesting in two regards. First, the 16 states showing positive productivity growth had been growing with a high average productivity growth of $7 \%$ to $54.9 \%$. In particular, the productivity growth rates in West Virginia, Texas, Utah, Vermont, Washington, Wyoming, and Wisconsin 
Table 3. Malmquist productivity and its decomposition in the pooled model of the U.S. transportation industry, 2004-2011.

\begin{tabular}{|c|c|c|c|}
\hline State & Efficiency change & Technological change & Productivity \\
\hline Alabama & 0.914 & 0.951 & 0.869 \\
\hline Alaska & 0.927 & 0.959 & 0.889 \\
\hline Arizona & 0.918 & 0.969 & 0.890 \\
\hline Arkansas & 0.969 & 0.967 & 0.937 \\
\hline California & 0.970 & 0.959 & 0.930 \\
\hline Colorado & 0.972 & 0.947 & 0.921 \\
\hline Connecticut & 0.914 & 0.967 & 0.884 \\
\hline Delaware & 0.940 & 0.964 & 0.906 \\
\hline District of Columbia & 1.013 & 0.975 & 0.988 \\
\hline Florida & 1.052 & 0.972 & 1.022 \\
\hline Georgia & 1.035 & 0.961 & 0.994 \\
\hline Hawaii & 0.988 & 0.978 & 0.966 \\
\hline Idaho & 0.964 & 0.972 & 0.937 \\
\hline Illinois & 0.922 & 0.955 & 0.880 \\
\hline Indiana & 0.876 & 0.959 & 0.840 \\
\hline Iowa & 0.859 & 0.948 & 0.814 \\
\hline Kansas & 1.119 & 0.956 & 1.070 \\
\hline Kentucky & 1.108 & 0.960 & 1.063 \\
\hline Louisiana & 1.102 & 0.958 & 1.056 \\
\hline Maine & 1.101 & 0.966 & 1.064 \\
\hline Maryland & 1.116 & 0.960 & 1.072 \\
\hline Massachusetts & 1.084 & 0.954 & 1.034 \\
\hline Michigan & 1.047 & 0.964 & 1.010 \\
\hline Minnesota & 1.051 & 0.952 & 1.000 \\
\hline Mississippi & 0.839 & 0.957 & 0.803 \\
\hline Missouri & 0.858 & 0.968 & 0.830 \\
\hline Montana & 0.846 & 0.950 & 0.803 \\
\hline Nebraska & 0.984 & 0.964 & 0.949 \\
\hline Nevada & 0.976 & 0.953 & 0.930 \\
\hline New Hampshire & 0.968 & 0.961 & 0.931 \\
\hline New Jersey & 0.959 & 0.955 & 0.916 \\
\hline New Mexico & 0.961 & 0.941 & 0.905 \\
\hline New York & 1.179 & 0.944 & 1.113 \\
\hline North Carolina & 1.188 & 0.969 & 1.151 \\
\hline North Dakota & 1.184 & 0.969 & 1.148 \\
\hline
\end{tabular}




\section{Continued}

\begin{tabular}{clll}
\hline Ohio & 1.177 & 0.963 & 1.134 \\
Oklahoma & 1.192 & 0.957 & 1.141 \\
Oregon & 1.159 & 0.950 & 1.101 \\
Pennsylvania & 1.114 & 0.960 & 1.069 \\
Rhode Island & 1.127 & 0.961 & 1.083 \\
South Carolina & 1.166 & 0.957 & 1.115 \\
South Dakota & 1.170 & 0.965 & 1.129 \\
Tennessee & 1.155 & 0.973 & 1.123 \\
Texas & 1.239 & 0.970 & 1.201 \\
Utah & 1.195 & 0.963 & 1.151 \\
Vermont & 1.182 & 0.951 & 1.125 \\
Virginia & 1.179 & 0.962 & 1.135 \\
Washington & 1.206 & 0.962 & 1.160 \\
West Virginia & 1.190 & 0.963 & 1.147 \\
Wisconsin & 1.165 & 0.971 & 1.131 \\
Wyoming & 1.161 & 0.972 & 1.128 \\
Average & 1.046 & 0.961 & 1.005 \\
\hline & & & \\
\hline & & & 0.963 \\
\hline
\end{tabular}

Table 4. Malmquist productivity and its decomposition in the airline transportation industry in the U.S., 2004-2011.

\begin{tabular}{cccc}
\hline State & Efficiency change & Technological change & Productivity \\
\hline Alabama & 1.031 & 0.979 & 1.009 \\
Alaska & 1.013 & 0.995 & 1.008 \\
Arizona & 1.030 & 1.039 & 1.070 \\
Arkansas & 1.070 & 0.967 & 1.034 \\
California & 1.046 & 0.944 & 0.988 \\
Colorado & 0.996 & 1.007 & 1.003 \\
Connecticut & 0.934 & 0.991 & 0.925 \\
Delaware & 0.944 & 0.983 & 0.927 \\
District of Columbia & 0.941 & 0.979 & 0.922 \\
Florida & 0.908 & 0.995 & 0.903 \\
Georgia & 0.908 & 1.039 & 0.943 \\
Hawaii & 1.056 & 0.967 & 1.021 \\
Idaho & 1.005 & 0.944 & 0.950 \\
Illinois & 0.953 & 1.007 & 0.960 \\
Indiana & 0.953 & 0.991 & 0.944 \\
Iowa & 0.964 & 0.983 & 0.947 \\
\hline
\end{tabular}




\section{Continued}

\begin{tabular}{|c|c|c|c|}
\hline Kansas & 0.999 & 0.979 & 0.978 \\
\hline Kentucky & 0.998 & 0.995 & 0.993 \\
\hline Louisiana & 1.013 & 1.039 & 1.052 \\
\hline Maine & 1.112 & 0.967 & 1.075 \\
\hline Maryland & 1.076 & 0.944 & 1.016 \\
\hline Massachusetts & 1.000 & 1.007 & 1.007 \\
\hline Michigan & 0.980 & 0.991 & 0.971 \\
\hline Minnesota & 0.991 & 0.983 & 0.974 \\
\hline Mississippi & 0.942 & 0.979 & 0.922 \\
\hline Missouri & 0.961 & 0.995 & 0.956 \\
\hline Montana & 0.971 & 1.039 & 1.009 \\
\hline Nebraska & 1.026 & 0.967 & 0.992 \\
\hline Nevada & 1.018 & 0.944 & 0.961 \\
\hline New Hampshire & 0.952 & 1.007 & 0.959 \\
\hline New Jersey & 0.914 & 0.991 & 0.905 \\
\hline New Mexico & 0.928 & 0.983 & 0.912 \\
\hline New York & 0.971 & 0.979 & 0.950 \\
\hline North Carolina & 1.099 & 0.995 & 1.093 \\
\hline North Dakota & 1.055 & 1.039 & 1.097 \\
\hline Ohio & 1.133 & 0.967 & 1.095 \\
\hline Oklahoma & 1.093 & 0.944 & 1.032 \\
\hline Oregon & 1.023 & 1.007 & 1.030 \\
\hline Pennsylvania & 1.014 & 0.991 & 1.005 \\
\hline Rhode Island & 1.041 & 0.983 & 1.023 \\
\hline South Carolina & 0.997 & 0.979 & 0.976 \\
\hline South Dakota & 0.996 & 0.995 & 0.991 \\
\hline Tennessee & 0.963 & 1.039 & 1.001 \\
\hline Texas & 1.141 & 0.967 & 1.103 \\
\hline Utah & 1.129 & 0.944 & 1.066 \\
\hline Vermont & 1.048 & 1.007 & 1.055 \\
\hline Virginia & 1.026 & 0.991 & 1.017 \\
\hline Washington & 1.079 & 0.983 & 1.061 \\
\hline West Virginia & 1.041 & 0.979 & 1.020 \\
\hline Wisconsin & 1.045 & 0.995 & 1.040 \\
\hline Wyoming & 1.061 & 1.039 & 1.103 \\
\hline Average & 1.01 & 0.989 & 0.998 \\
\hline
\end{tabular}




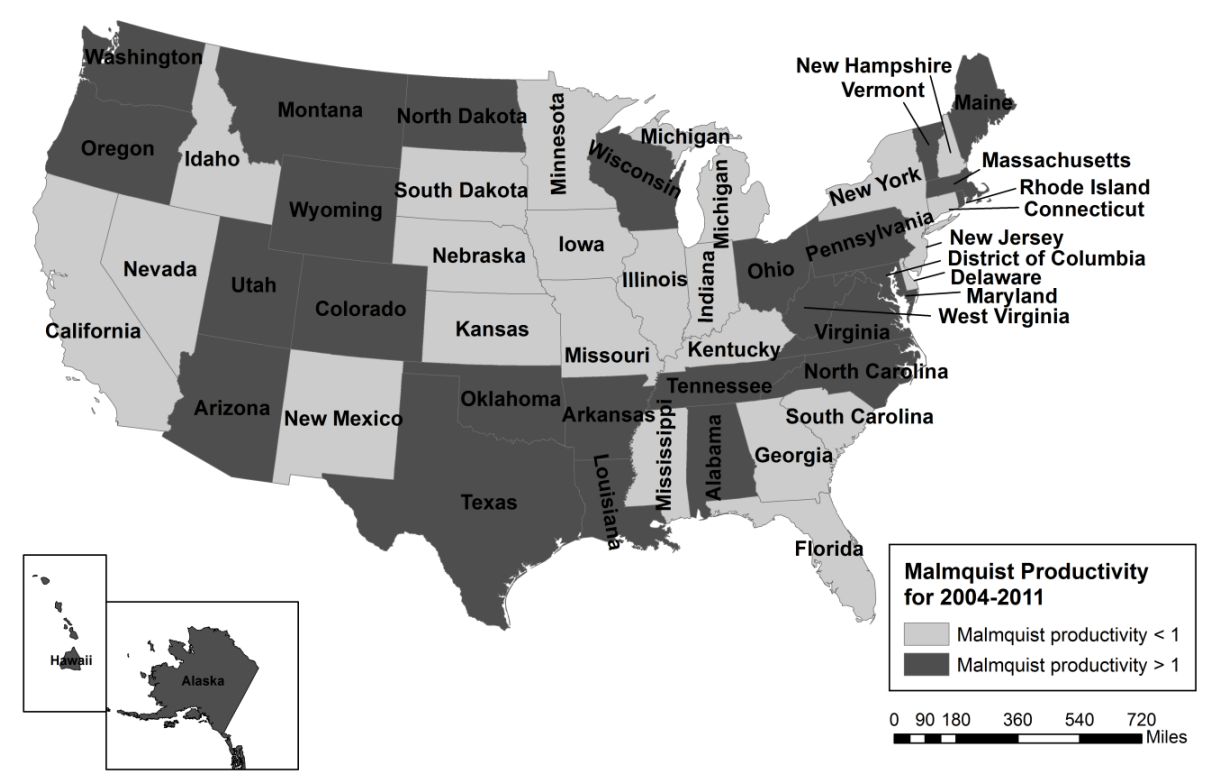

Figure 2. Geographic representation of average Malmquist productivity for 2004-2011 by state in the airline transportation industry.

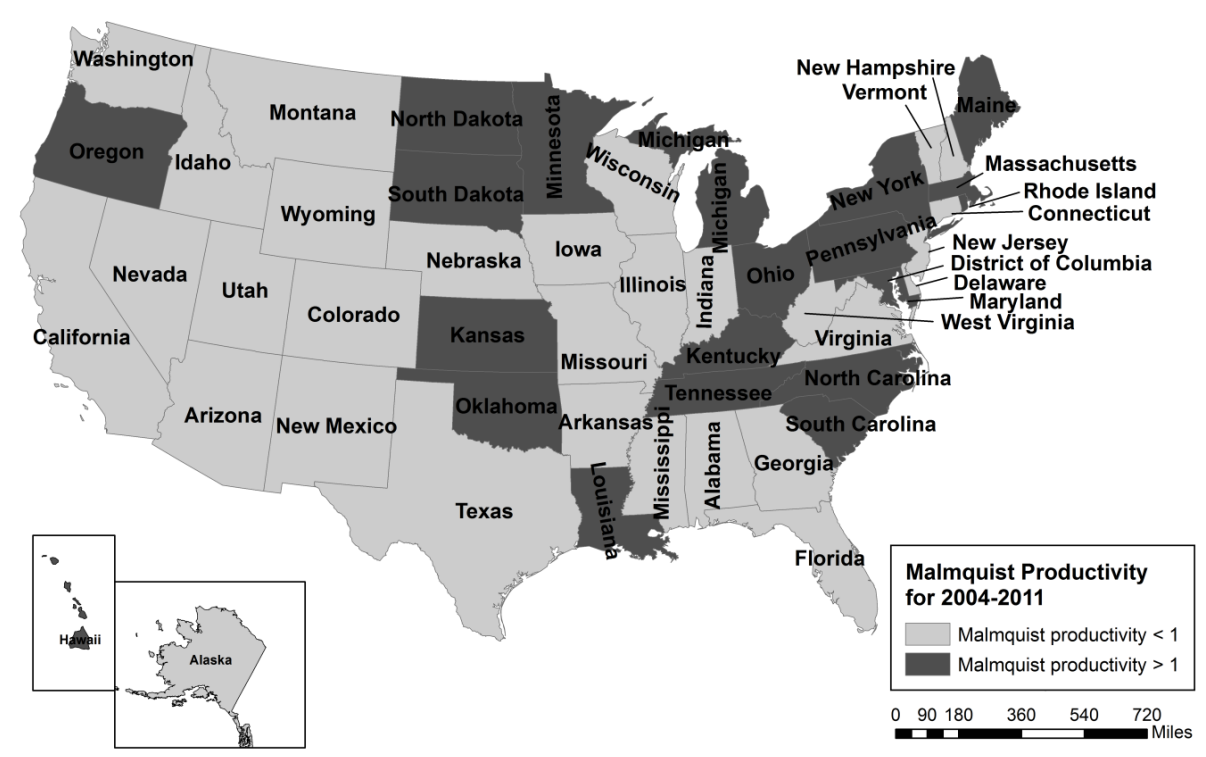

Figure 3. Geographic representation of average Malmquist productivity for 2004-2011 by state in the truck transportation industry.

reach 54.9\%, 47.7\%, 46.9\%, 41.9\%, 37.1\%, 37.1\%, and 36.8\%, respectively. Second, all 49 states show at least $0.8 \%$ annual average innovation growth, meaning that innovation has been continuously shifting on average. Figure 4 depicts the geographic representation of average productivity for 2004-2011 by state in the rail transportation industry.

Table 7 shows the change in Malmquist productivity and its decomposition in the pipeline transportation industry by state from 2004 to 2011. On average, the productivity decline by state in this industry is the highest of the five major transportation industries, showing $-11.2 \%$. This is explained by the severe annual average technological decline of $18.3 \%$ and the $10 \%$ increase in efficiency change. Excluding the seven states of Maryland, Massachusetts, Michigan, Minnesota, Mississippi, Missouri, and West Virginia, the productivity change in the remaining states averages much less than zero. Innovation in all states had been declining with much lower technological change, with some states even showing decreases in both efficiency and technological change: 
Table 5. Malmquist productivity and its decomposition in the truck transportation industry in the U.S., 2004-2011.

\begin{tabular}{|c|c|c|c|}
\hline State & Efficiency change & Technological change & Productivity \\
\hline Alabama & 0.981 & 0.971 & 0.953 \\
\hline Alaska & 0.961 & 0.98 & 0.942 \\
\hline Arizona & 0.964 & 0.975 & 0.939 \\
\hline Arkansas & 0.974 & 0.972 & 0.946 \\
\hline California & 0.956 & 0.977 & 0.934 \\
\hline Colorado & 0.94 & 0.974 & 0.915 \\
\hline Connecticut & 0.924 & 0.968 & 0.894 \\
\hline Delaware & 0.955 & 0.965 & 0.921 \\
\hline District of Columbia & 1.004 & 0.971 & 0.975 \\
\hline Florida & 0.991 & 0.98 & 0.971 \\
\hline Georgia & 1.008 & 0.975 & 0.983 \\
\hline Hawaii & 1.039 & 0.972 & 1.009 \\
\hline Idaho & 0.992 & 0.977 & 0.969 \\
\hline Illinois & 0.97 & 0.974 & 0.944 \\
\hline Indiana & 0.982 & 0.968 & 0.95 \\
\hline Iowa & 0.996 & 0.965 & 0.961 \\
\hline Kansas & 1.226 & 0.971 & 1.191 \\
\hline Kentucky & 1.19 & 0.98 & 1.167 \\
\hline Louisiana & 1.195 & 0.975 & 1.165 \\
\hline Maine & 1.117 & 0.972 & 1.086 \\
\hline Maryland & 1.116 & 0.977 & 1.09 \\
\hline Massachusetts & 1.075 & 0.974 & 1.047 \\
\hline Michigan & 1.103 & 0.968 & 1.068 \\
\hline Minnesota & 1.09 & 0.965 & 1.051 \\
\hline Mississippi & 0.843 & 0.971 & 0.819 \\
\hline Missouri & 0.827 & 0.98 & 0.811 \\
\hline Montana & 0.828 & 0.975 & 0.807 \\
\hline Nebraska & 0.971 & 0.972 & 0.944 \\
\hline Nevada & 0.962 & 0.977 & 0.94 \\
\hline New Hampshire & 0.956 & 0.974 & 0.931 \\
\hline New Jersey & 0.966 & 0.968 & 0.935 \\
\hline New Mexico & 0.968 & 0.965 & 0.934 \\
\hline New York & 1.062 & 0.971 & 1.032 \\
\hline North Carolina & 1.084 & 0.98 & 1.063 \\
\hline North Dakota & 1.089 & 0.975 & 1.061 \\
\hline
\end{tabular}




\begin{tabular}{cccc} 
Continued & & & \\
\hline Ohio & 1.068 & 0.972 & 1.038 \\
Oklahoma & 1.076 & 0.977 & 1.051 \\
Oregon & 1.047 & 0.974 & 1.02 \\
Pennsylvania & 1.059 & 0.968 & 1.025 \\
Rhode Island & 1.065 & 0.965 & 1.028 \\
South Carolina & 1.049 & 0.971 & 1.019 \\
South Dakota & 1.042 & 0.98 & 1.021 \\
Tennessee & 1.038 & 0.975 & 1.011 \\
Texas & 0.947 & 0.972 & 0.92 \\
Utah & 0.942 & 0.977 & 0.92 \\
Vermont & 0.918 & 0.974 & 0.894 \\
Virginia & 0.969 & 0.968 & 0.938 \\
Washington & 0.965 & 0.965 & 0.931 \\
West Virginia & 0.992 & 0.971 & 0.964 \\
Wisconsin & 0.981 & 0.98 & 0.962 \\
Wyoming & 0.989 & 0.975 & 0.964 \\
Average & 1.006 & 0.973 & 0.978 \\
\hline
\end{tabular}

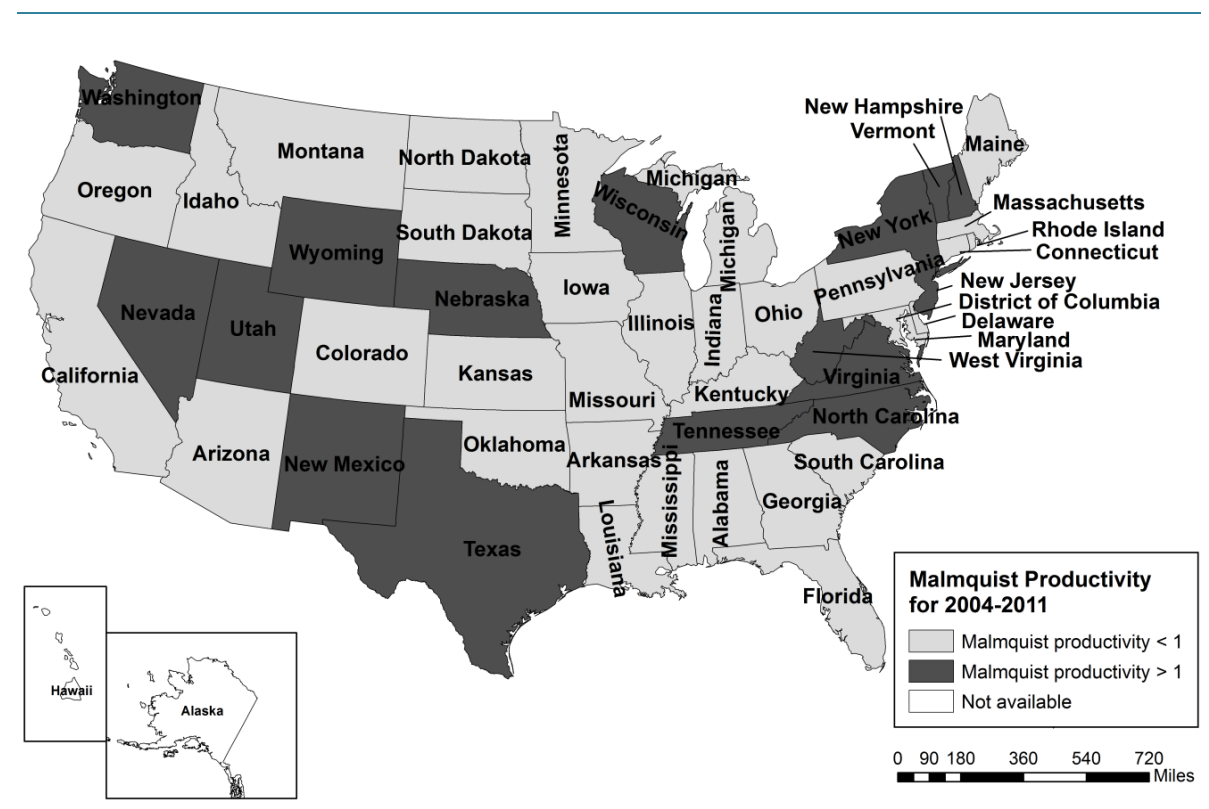

Figure 4. Geographic representation of average Malmquist productivity for 2004-2011 by state in the rail transportation industry.

Florida, Louisiana, North Dakota, Ohio, Oklahoma, Pennsylvania, South Carolina, and Tennessee. Figure 5 depicts the geographic representation of average productivity for 2004-2011 by state in the pipeline transportation industry.

In Table 8, Malmquist productivity and its decomposition in the water transportation industry are shown between 2004 and 2011. Average productivity growth in the water transportation industry in each state shows close to zero growth or a slight increase. On average, productivity growth is $0.1 \%$, which is decomposed into an 
Table 6. Malmquist productivity and its decomposition in the rail transportation industry in the U.S., 2004-2011.

\begin{tabular}{|c|c|c|c|}
\hline State & Efficiency change & Technological change & Productivity \\
\hline Alabama & 0.885 & 1.031 & 0.912 \\
\hline Arizona & 0.772 & 1.026 & 0.793 \\
\hline Arkansas & 0.762 & 1.072 & 0.817 \\
\hline California & 0.768 & 1.052 & 0.808 \\
\hline Colorado & 0.763 & 1.008 & 0.769 \\
\hline Connecticut & 0.786 & 1.037 & 0.816 \\
\hline Delaware & 0.811 & 1.064 & 0.862 \\
\hline District of Columbia & 0.793 & 1.059 & 0.839 \\
\hline Florida & 0.835 & 1.031 & 0.861 \\
\hline Georgia & 0.845 & 1.026 & 0.867 \\
\hline Idaho & 0.812 & 1.072 & 0.870 \\
\hline Illinois & 0.823 & 1.052 & 0.865 \\
\hline Indiana & 0.813 & 1.008 & 0.819 \\
\hline Iowa & 0.828 & 1.037 & 0.859 \\
\hline Kansas & 0.867 & 1.064 & 0.922 \\
\hline Kentucky & 0.835 & 1.059 & 0.884 \\
\hline Louisiana & 0.796 & 1.031 & 0.821 \\
\hline Maine & 0.847 & 1.026 & 0.869 \\
\hline Maryland & 0.843 & 1.072 & 0.904 \\
\hline Massachusetts & 0.871 & 1.052 & 0.915 \\
\hline Michigan & 0.844 & 1.008 & 0.851 \\
\hline Minnesota & 0.815 & 1.037 & 0.845 \\
\hline Mississippi & 0.836 & 1.064 & 0.889 \\
\hline Missouri & 0.821 & 1.059 & 0.869 \\
\hline Montana & 0.907 & 1.031 & 0.935 \\
\hline Nebraska & 1.043 & 1.026 & 1.070 \\
\hline Nevada & 1.023 & 1.072 & 1.097 \\
\hline New Hampshire & 1.072 & 1.052 & 1.127 \\
\hline New Jersey & 1.084 & 1.008 & 1.092 \\
\hline New Mexico & 1.111 & 1.037 & 1.152 \\
\hline New York & 1.152 & 1.064 & 1.226 \\
\hline North Carolina & 1.076 & 1.059 & 1.139 \\
\hline North Dakota & 0.942 & 1.031 & 0.971 \\
\hline Ohio & 0.916 & 1.026 & 0.940 \\
\hline Oklahoma & 0.898 & 1.072 & 0.963 \\
\hline
\end{tabular}




\section{Continued}

\begin{tabular}{clll}
\hline Oregon & 0.901 & 1.052 & 0.948 \\
Pennsylvania & 0.879 & 1.008 & 0.886 \\
Rhode Island & 0.890 & 1.037 & 0.923 \\
South Carolina & 0.903 & 1.064 & 0.961 \\
South Dakota & 0.893 & 1.059 & 0.945 \\
Tennessee & 1.161 & 1.031 & 1.197 \\
Texas & 1.439 & 1.026 & 1.477 \\
Utah & 1.370 & 1.072 & 1.469 \\
Vermont & 1.349 & 1.052 & 1.419 \\
Virginia & 1.279 & 1.008 & 1.289 \\
Washington & 1.322 & 1.037 & 1.371 \\
West Virginia & 1.457 & 1.064 & 1.549 \\
Wisconsin & 1.292 & 1.059 & 1.368 \\
Wyoming & 1.330 & 1.031 & 1.371 \\
Average & 0.948 & 1.043 & 0.989 \\
\hline
\end{tabular}

Note: Rail transportation information for Alaska and Hawaii is not available in the BEA online database, so 49 states are used for this productivity analysis.

Table 7. Malmquist productivity and its decomposition in the pipeline transportation industry in the U.S., 2004-2011.

\begin{tabular}{cccc}
\hline State & Efficiency change & Technological change & Productivity \\
\hline Alabama & 1.047 & 0.815 & 0.854 \\
Alaska & 1.107 & 0.816 & 0.903 \\
Arizona & 1.122 & 0.815 & 0.915 \\
Arkansas & 1.078 & 0.820 & 0.884 \\
California & 1.211 & 0.821 & 0.994 \\
Colorado & 1.061 & 0.815 & 0.865 \\
Connecticut & 1.061 & 0.815 & 0.865 \\
Florida & 0.896 & 0.815 & 0.730 \\
Georgia & 1.106 & 0.815 & 0.902 \\
Idaho & 1.122 & 0.816 & 0.916 \\
Illinois & 1.123 & 0.815 & 0.915 \\
Indiana & 1.079 & 0.820 & 0.885 \\
Iowa & 1.202 & 0.821 & 0.987 \\
Kansas & 1.037 & 0.815 & 0.846 \\
Kentucky & 1.080 & 0.815 & 0.880 \\
Louisiana & 0.930 & 0.815 & 0.758 \\
Maine & 1.208 & 0.815 & 0.984 \\
\hline & & & \\
\hline & & & \\
\hline
\end{tabular}




\section{Continued}

\begin{tabular}{|c|c|c|c|}
\hline Maryland & 1.253 & 0.816 & 1.022 \\
\hline Massachusetts & 1.265 & 0.815 & 1.032 \\
\hline Michigan & 1.233 & 0.820 & 1.011 \\
\hline Minnesota & 1.431 & 0.821 & 1.174 \\
\hline Mississippi & 1.232 & 0.815 & 1.004 \\
\hline Missouri & 1.337 & 0.815 & 1.089 \\
\hline Montana & 1.171 & 0.815 & 0.954 \\
\hline Nebraska & 1.097 & 0.815 & 0.894 \\
\hline Nevada & 1.126 & 0.816 & 0.919 \\
\hline New Hampshire & 1.144 & 0.815 & 0.933 \\
\hline New Jersey & 1.081 & 0.820 & 0.887 \\
\hline New Mexico & 1.170 & 0.821 & 0.960 \\
\hline New York & 1.036 & 0.815 & 0.844 \\
\hline North Carolina & 1.055 & 0.815 & 0.860 \\
\hline North Dakota & 0.846 & 0.815 & 0.689 \\
\hline Ohio & 0.964 & 0.815 & 0.785 \\
\hline Oklahoma & 0.984 & 0.816 & 0.803 \\
\hline Oregon & 1.013 & 0.815 & 0.826 \\
\hline Pennsylvania & 0.995 & 0.820 & 0.816 \\
\hline Rhode Island & 1.145 & 0.821 & 0.939 \\
\hline South Carolina & 0.992 & 0.815 & 0.808 \\
\hline South Dakota & 1.012 & 0.815 & 0.824 \\
\hline Tennessee & 0.883 & 0.815 & 0.720 \\
\hline Texas & 1.103 & 0.815 & 0.899 \\
\hline Utah & 1.141 & 0.816 & 0.931 \\
\hline Virginia & 1.162 & 0.815 & 0.947 \\
\hline Washington & 1.137 & 0.820 & 0.933 \\
\hline West Virginia & 1.242 & 0.821 & 1.019 \\
\hline Wisconsin & 1.094 & 0.815 & 0.892 \\
\hline Wyoming & 1.143 & 0.815 & 0.931 \\
\hline Average & 1.100 & 0.817 & 0.898 \\
\hline
\end{tabular}

Note: Pipeline transportation information for District of Columbia, Delaware, Hawaii, and Vermont is not available in the BEA online database, so 47 states are used for the productivity analysis.

increase of $2.3 \%$ in efficiency change and a decrease of $2.2 \%$ in technological change. Like the truck transportation industry, each water transportation industry in the 38 states shows all negative technological changes, but the productivity changes in the 18 states show growth. The following states having an average productivity growth of more than 10\%: Arizona (18.1\%), North Carolina (16.4\%), South Carolina (15.3\%), Pennsylvania (13.9\%), Connecticut (13.9\%), Rhode Island (13.2\%), Ohio (11.1\%), and Alaska (10.9\%). Figure 6 depicts the geographic representation of average productivity for 2004-2011 by state in the water transportation industry. 


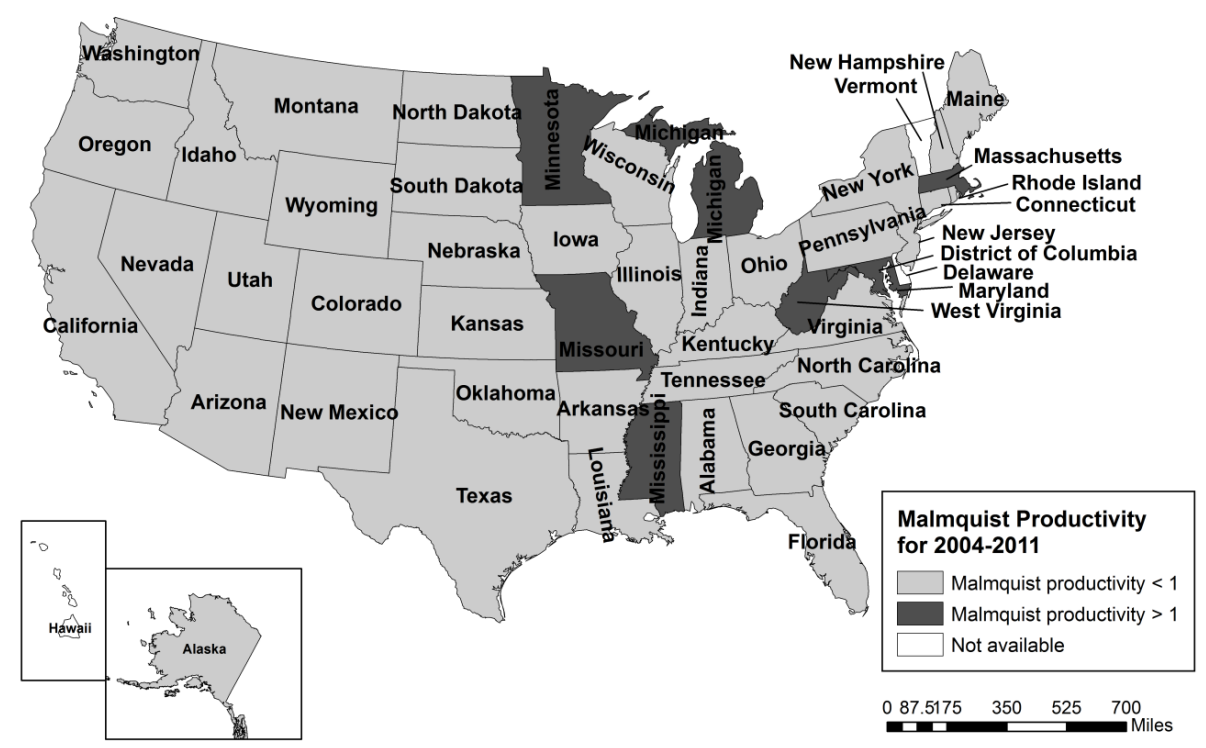

Figure 5. Geographic representation of average Malmquist productivity for 2004-2011 by state in the pipeline transportation industry.

Table 8. Malmquist productivity and its decomposition in the water transportation industry in the U.S., 2004-2011.

\begin{tabular}{|c|c|c|c|}
\hline State & Efficiency change & Technological change & Productivity \\
\hline Alabama & 1.087 & 0.978 & 1.063 \\
\hline Alaska & 1.147 & 0.967 & 1.109 \\
\hline Arizona & 1.197 & 0.987 & 1.181 \\
\hline Arkansas & 1.115 & 0.977 & 1.090 \\
\hline California & 1.082 & 0.978 & 1.058 \\
\hline Connecticut & 1.150 & 0.991 & 1.139 \\
\hline District of Columbia & 1.051 & 0.969 & 1.018 \\
\hline Florida & 1.078 & 0.980 & 1.056 \\
\hline Georgia & 1.111 & 0.978 & 1.086 \\
\hline Hawaii & 1.057 & 0.967 & 1.021 \\
\hline Illinois & 1.031 & 0.987 & 1.017 \\
\hline Indiana & 1.010 & 0.977 & 0.988 \\
\hline Iowa & 1.000 & 0.978 & 0.978 \\
\hline Kentucky & 1.000 & 0.991 & 0.991 \\
\hline Louisiana & 0.849 & 0.969 & 0.822 \\
\hline Maine & 0.864 & 0.980 & 0.846 \\
\hline Maryland & 1.035 & 0.978 & 1.012 \\
\hline Massachusetts & 1.002 & 0.967 & 0.968 \\
\hline Michigan & 0.947 & 0.987 & 0.934 \\
\hline Mississippi & 0.999 & 0.977 & 0.977 \\
\hline
\end{tabular}




\section{Continued}

\begin{tabular}{|c|c|c|c|}
\hline Missouri & 0.973 & 0.978 & 0.952 \\
\hline New Jersey & 0.915 & 0.991 & 0.907 \\
\hline New Mexico & 0.993 & 0.969 & 0.962 \\
\hline New York & 0.997 & 0.980 & 0.977 \\
\hline North Carolina & 1.191 & 0.978 & 1.164 \\
\hline Ohio & 1.149 & 0.967 & 1.111 \\
\hline Oregon & 1.092 & 0.987 & 1.077 \\
\hline Pennsylvania & 1.165 & 0.977 & 1.139 \\
\hline Rhode Island & 1.158 & 0.978 & 1.132 \\
\hline South Carolina & 1.164 & 0.991 & 1.153 \\
\hline Tennessee & 0.974 & 0.969 & 0.943 \\
\hline Texas & 0.992 & 0.980 & 0.972 \\
\hline Utah & 0.951 & 0.978 & 0.930 \\
\hline Vermont & 0.942 & 0.967 & 0.910 \\
\hline Virginia & 0.918 & 0.987 & 0.906 \\
\hline Washington & 0.883 & 0.977 & 0.864 \\
\hline West Virginia & 0.891 & 0.978 & 0.871 \\
\hline Wisconsin & 0.904 & 0.991 & 0.896 \\
\hline Average & 1.023 & 0.978 & 1.001 \\
\hline
\end{tabular}

Note: Water transportation information for Colorado, Delaware, Idaho, Kansas, Montana, Nebraska, Nevada, New Hampshire, Minnesota, North Dakota, Oklahoma, South Dakota, and Wyoming is not available in the BEA online database, so 38 states are used for the productivity analysis.

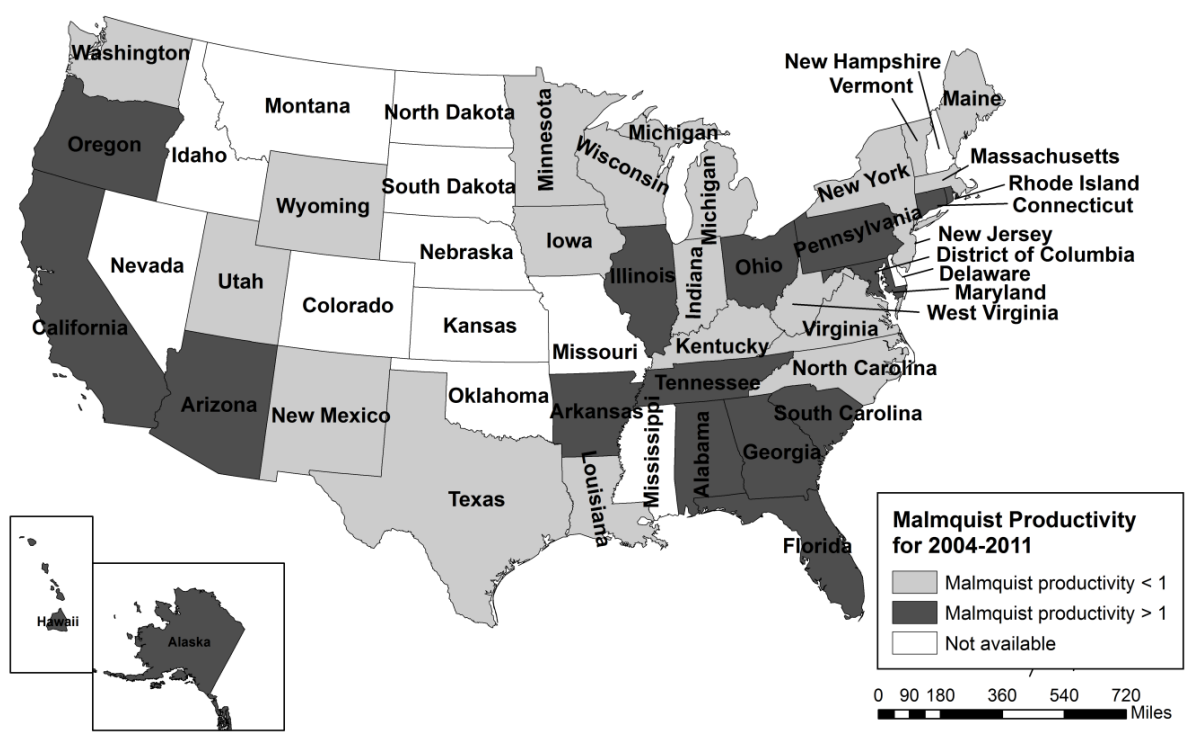

Figure 6. Geographic representation of average Malmquist productivity for 2004-2011 by state in the water transportation industry. 
Table 9 summarizes the annual average productivity and efficiency and technological change in the five major transportation industries and the pooled transportation industry for 2004 to 2011 . As is known, an unexpected global financial crisis occurred in 2007, 2008, and 2010, which negatively affected U.S. industry. As a result, each transportation industry had been growing at different rates corresponding to the U.S. economic recovery.

The major findings are as follows. First, the pooled transportation representing the U.S. transportation industry shows productivity growth of $21.7 \%$ in 2011 as well as a strong and positive trend except in the years of 2007, 2008, and 2010. Second, the airline transportation industry shows a severe drop in productivity growth during the years of the global financial crisis, but high productivity growth in 2005, 2009, and 2011. Third, the truck transportation industry grew in 2007 and 2010, but recently shows a decrease in productivity growth and even a decline in 2011 at $16.4 \%$. Fourth, productivity growth in the rail transportation industry exponentially increased except in those three years. Indeed, the distinct productivity growth levels of $50.2 \%$ in $2006,81.5 \%$ in 2009, and $91.6 \%$ in 2011 are surprising. Fifth, the pipeline transportation industry grew sharply until 2008, but after that point, productivity declines drifted. This industry show a productivity decline with the truck transportation industry in 2011. Finally, the water transportation industry on average shows at least $10 \%$ productivity growth out of the years of the financial crisis, but particularly almost close to zero in 2009. It is also ranked the second highest productivity growth in 2011 (37\%). Overall, efficiency and technological change shows a mixed increase or decrease over time in each industry and the pooled transportation industry, but their productivities have predictable increasing or decreasing trends. Figure 7 depicts the productivities of each transportation industry and the pooled transportation industry for 2005, 2006, 2009, and 2011.

\section{Conclusions}

The U.S. transportation industry contributes over one-tenth of U.S. GDP, and thus its productivity growth is importantly connected to the growth of the entire U.S. economy. In this study, we measured productivity growth in

Table 9. Productivity and efficiency and technological change in each industry and the pooled industry during the period of 2005 to 2011.

\begin{tabular}{ccccccccc}
\hline Productivity & $\mathbf{2 0 0 5}$ & $\mathbf{2 0 0 6}$ & $\mathbf{2 0 0 7}$ & $\mathbf{2 0 0 8}$ & $\mathbf{2 0 0 9}$ & $\mathbf{2 0 1 0}$ & $\mathbf{2 0 1 1}$ & Average \\
\hline Airline transportation & 1.389 & 0.862 & 0.783 & 0.836 & 1.327 & 0.840 & 1.132 & 0.998 \\
Truck transportation & 0.642 & 1.322 & 1.039 & 0.872 & 1.208 & 1.105 & 0.836 & 0.978 \\
Rail transportation & 0.476 & 1.502 & 1.216 & 0.660 & 1.815 & 0.464 & 1.916 & 0.989 \\
Pipeline transportation & 0.494 & 1.035 & 1.087 & 1.921 & 0.752 & 0.829 & 0.707 & 0.898 \\
Water transportation & 1.176 & 1.121 & 0.870 & 0.917 & 0.990 & 0.708 & 1.370 & 1.001 \\
Pooled transportation & 0.662 & 1.485 & 0.831 & 0.951 & 1.291 & 0.848 & 1.217 & 1.005 \\
\hline
\end{tabular}

Note: There is no base year to calculate productivity for 2004.

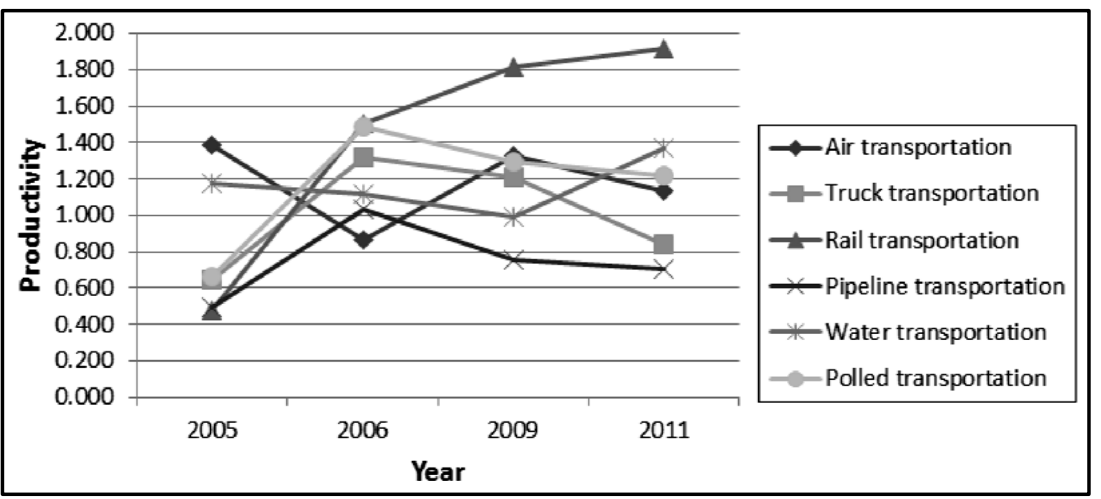

Figure 7. Annual average Malmquist productivities of each transportation industry and the pooled transportation industry for 2005, 2006, 2009, and 2011. 
the five major transportation industries of airline, truck, rail, pipeline, and water as well as the pooled transportation industry for 2004-2011 and decomposed this growth into efficiency and technological change to provide its fundamental driving forces. This study separately found the results of average productivity for the eight years by state in each transportation industry and the annual average productivities for the transportation industries themselves. Although the average productivity growth by state in these transportation industries was on average close to zero or slightly increasing, the overall U.S. transportation industry grew with a strong and positive trend with noteworthy productivity growth of $21.7 \%$ in 2011, except that in the years of the global financial crisis in 2007, 2008, and 2010. The rail and water transportation industries had the first and second highest productivity growth in 2011, which might have been as a result of the growth in sustainable transport modes globally.

This study had a limitation based on the data used. The intermediate inputs for each state were estimated to find the best-possible approximation through the extent of taxes that each state collected; if original data on energy, materials, and purchased-service inputs in the BEA were available to the public, we could estimate more accurate results for productivity growth in the U.S. transportation industry.

\section{Acknowledgements}

This research was part of Jaesung Choi's dissertation. The authors would like to thank anonymous reviewers for their constructive comments.

\section{References}

[1] Rodrigue, J.P. and Notteboom, T. (2013) The Geography of Transport Systems.

[2] The United States Department of Transportation (2014) Growth in the Nation's Freight Shipments. http://www.rita.dot.gov/bts/sites/rita.dot.gov.bts/files/publications/freight shipments in america/html/entire.html

[3] Färe, R., Grosskopf, S., Lindgren, B. and Roos, P. (1992) Productivity Changes in Swedish Pharamacies 1980-1989: A Non-Parametic Malmquist Approach. The Journal of Productivity Analysis, 3, 85-101. http://dx.doi.org/10.1007/BF00158770

[4] Färe, R. and Grosskopf, S. (1994) Theory and Calculation of Productivity Indexes. In: Models and Measurement of Welfare and Inequality, Springer, Berlin, Heidelberg, New York, 921-940.

[5] Färe, R., Grosskopf, S., Norris, M. and Zhang, Z.Y. (1994) Productivity Growth, Technical Progress, and Efficiency Change in Industrialized Countries. American Economic Review, 84, 66-83.

[6] Färe, R., Grosskopf, S., Lindgren, B. and Roos, P. (1994) Data Envelopment Analysis: Theory, Methodology, and Application. Kluwer Academic Publishers, Dordrecht, 253-272.

[7] Hjalmarsson, L., Kumbhakar, S.C. and Heshmati, A. (1996) DEA, DFA and SFA: A Comparison. Journal of Productivity Analysis, 7, 303-327. http://dx.doi.org/10.1007/BF00157046

[8] Celen, A. (2013) Efficiency and Productivity (TFP) of the Turkish Electricity Distribution Companies: An Application of Two-Stage (DEA\&Tobit) Analysis. Energy Policy, 63, 300-310. http://dx.doi.org/10.1016/j.enpol.2013.09.034

[9] Farrell, M. (1957) The Measurement of Productive Efficiency. Journal of the Royal Statistical Society, 120, $253-290$. http://dx.doi.org/10.2307/2343100

[10] Charnes, A., Cooper, W. and Rhodes, E. (1978) Measuring the Efficiency of Decision Making Units. European Journal of Operational Research, 2, 429-444. http://dx.doi.org/10.1016/0377-2217(78)90138-8

[11] Caves, D.W., Christensen, L.R. and Diewert, W.E. (1982) The Economic Theory of Index Numbers and the Measurement of Input, Output, and Productivity. Econometrica, 50, 1393-1414. http://dx.doi.org/10.2307/1913388

[12] Sueyoshi, T. (1992) Measuring Technical, Allocative and Overall Efficiencies Using a DEA Algorism. Journal of the Operational Research Society, 43, 141-155. http://dx.doi.org/10.1057/jors.1992.19

[13] Ball, V., Lovell, C., Luu, H. and Nehring, R. (2004) Incorporating Environmental Impacts in the Measurement of Agricultural Productivity Growth. Journal of Agricultural and Resource Economics, 29, 436-460.

[14] Heng, Y., Lim, S.H. and Chi, J. (2012) Toxic Air Pollutants and Trucking Productivity in the US. Transportation Research Part D, 17, 309-316. http://dx.doi.org/10.1016/j.trd.2012.01.001

[15] Sueyoshi, T. and Goto, M. (2013) DEA Environmental Assessment in a Time Horizon: Malmquist Index on Fuel Mix, Electricity and $\mathrm{CO}_{2}$ of Industrial Nations. Energy Economics, 40, 370-382. http://dx.doi.org/10.1016/j.eneco.2013.07.013

[16] Chen, Y. and Ali, A. (2004) DEA Malmquist Productivity Measure: New Insights with an Application to Computer Industry. European Journal of Operational Research, 159, 239-249. http://dx.doi.org/10.1016/S0377-2217(03)00406-5 
[17] Liu, F. and Wang, P. (2008) DEA Malmquist Productivity Measure: Taiwanese Semiconductor Companies. International Journal of Production Economics, 112, 367-379. http://dx.doi.org/10.1016/j.ijpe.2007.03.015

[18] Qazi, A. and Zhao, Y.L. (2012) Productivity Measurement of Hi-Tech Industry of China Malmquist Productivity Index-DEA Approach. Procedia Economics and Finance, 1, 330-336. http://dx.doi.org/10.1016/S2212-5671(12)00038-X

[19] Coelli, T. (1996) A Guide to DEAP Version 2.1: A Data Envelopment Analysis Program. Centre for Efficiency and Productivity Analysis (CEPA), Armidale.

[20] The United States Bureau of Economic Analysis (2013) Interactive Data. http://www.bea.gov/itable/

[21] The United States Department of Commerce (2014) Industry Data.

http://www.bea.gov/iTable/index industry gdpIndy.cfm

[22] Daniel, W.W. (1990) Applied Nonparametric Statistics. Duxbury, Pacific Grove. 
Scientific Research Publishing (SCIRP) is one of the largest Open Access journal publishers. It is currently publishing more than 200 open access, online, peer-reviewed journals covering a wide range of academic disciplines. SCIRP serves the worldwide academic communities and contributes to the progress and application of science with its publication.

Other selected journals from SCIRP are listed as below. Submit your manuscript to us via either submit@scirp.org or Online Submission Portal.
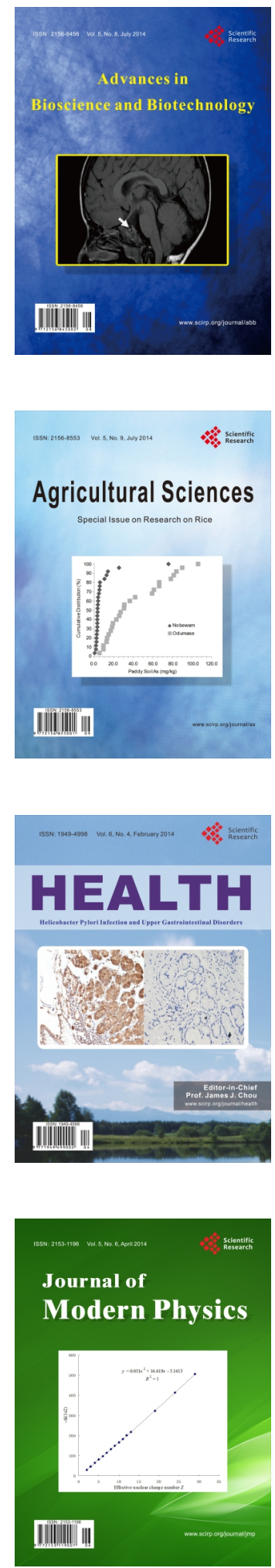
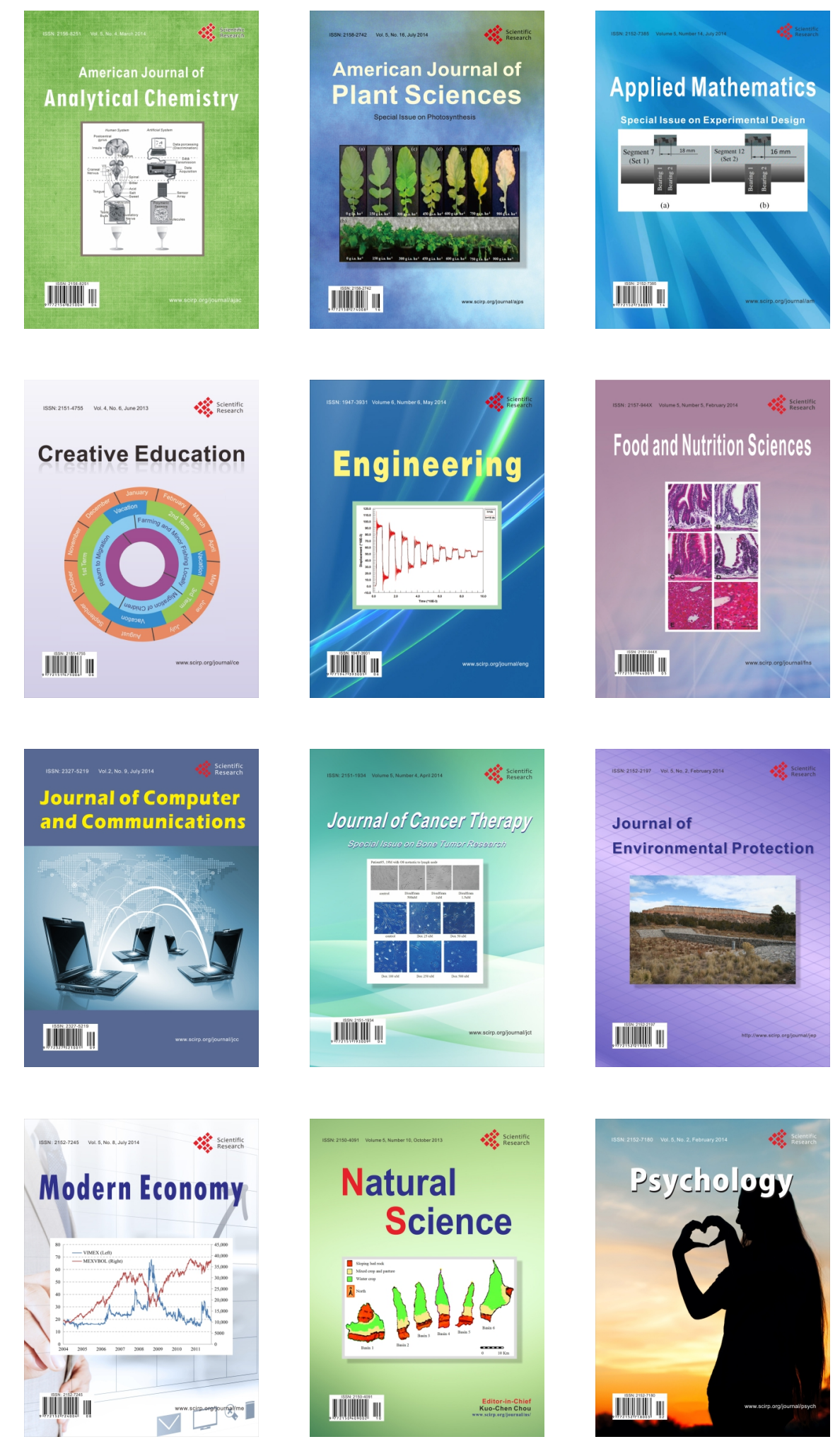